\title{
Enhanced drought tolerance in transgenic Swingle citrumelo overexpressing VaP5CS-F129A under the control of stress induced $R D 29 A$ promoter
}

\author{
Renato Farinacio ${ }^{1}$, Diliane Barichello ${ }^{1}$, Giselly Aparecida Andrade ${ }^{1}$, \\ Diego Aparecido Costalonga Leite ${ }^{1}$, Camilla Carvalho Nunes dos Santos ${ }^{1}$, \\ Mariane Silva Felicio ${ }^{2}$, Marília Kaphan Freitas de Campos $^{3}$, Glaucia Braz Alcantara ${ }^{4}$, \\ Luiz Gonzaga Esteves Vieira ${ }^{5} \&$ Eduardo Fermino Carlos $^{1}$
}

\section{SUMMARY}

In plants, water deficit causes morphological, molecular and physiological responses, including stomata closure, photosynthesis reduction and accumulation of cellular osmoprotective compounds such as proline. This amino acid influences important biological functions, for instance by helping the stabilization of proteins and intracellular membranes and by mitigating the negative effects of reactive oxygen species. The present work had the objective to evaluate the performance of two transgenic events (Ev.6 and Ev.8) of Swingle citrumelo (Citrus paradisi Macfad. cv. Duncan x Poncirus trifoliata L. Raf.) rootstock transformed with the mutant Vigna aconitifolia P5CS-F129A gene, which encodes the key enzyme $\Delta 1$-pyrroline-5-carboxylate synthetase (P5CS) for proline biosynthesis, under the control of the stress-responsive $R D 29 \mathrm{~A}$ promoter. Under greenhouse conditions, plants were left without irrigation up to reach severe stress level and then rehydrated after 31 days without watering. The event 8 (Ev.8) displayed significant increments of proline and higher photosynthesis, transpiration and stomata conductance rate throughout the stress period. Thus, because of its overall drought response, the plant 1329 of the Ev. 8 was selected for multiplication and future field competition tests under our citrus rootstock breeding program, aiming to select a Swingle citrumelo genotype more tolerant to water deficit.

Index terms: rootstock, drought tolerance, citrus, GMO, dry spell.

\section{Aumento da tolerância à seca em citrumelo Swingle transgênico super expressando o VaP5CS-F129A sob controle do promotor de estresse induzido RD29A}

\section{RESUMO}

Nas plantas, o déficit hídrico provoca respostas morfológicas, moleculares e fisiológicas, incluindo o fechamento de estômatos, a redução da fotossíntese e o acúmulo de compostos celulares osmoprotetores, como a prolina. Este aminoácido influencia funções biológicas importantes,

\footnotetext{
${ }^{1}$ Instituto Agronômico do Paraná - IAPAR, Londrina, PR, Brazil

${ }^{2}$ Programa de Pós-graduação em Ciências Biológicas (Genética), Universidade Estadual Paulista - UNESP, Botucatu, SP, Brazil

${ }^{3}$ Institut für Nutzpflanzenwissenschaften und Ressourcenschutz - INRES, University of Bonn, Bonn, Germany

${ }^{4}$ Universidade Federal de Mato Grosso do Sul - UFMS, Campo Grande, MS, Brazil

${ }^{5}$ Universidade do Oeste Paulista - UNOESTE, Presidente Prudente, SP, Brazil

Corresponding author: Eduardo Fermino Carlos, Instituto Agronômico do Paraná - IAPAR, Rodovia Celso Garcia Cid, km 375, CEP 86047-902, Londrina, PR, Brazil. E-mail: eduardo05061@gmail.com
} 
por exemplo, ajudando na estabilização de proteínas e membranas intracelulares e mitigando os efeitos negativos de espécies reativas de oxigênio. O presente trabalho teve como objetivo avaliar o desempenho de dois eventos transgênicos (Ev.6 e Ev.8) do porta-enxerto citrumelo Swingle (Citrus paradisi Macfad. Cv. Duncan x Poncirus trifoliata L. Raf.) transformados com o gene mutante P5CS-F129A de Vigna aconitifolia, que codifica a enzima chave $\Delta$ 1-pirrolina-5-carboxilato sintetase (P5CS) para a biossíntese de prolina, sob o controle do promotor estresse induzido RD29A. Em condições de casa de vegetação, as plantas foram mantidas sem irrigação até atingir o nível de estresse severo e então após 31 dias sem irrigação foram reidratadas. O evento 8 (Ev.8) apresentou incrementos significativos de prolina e maiores taxas de fotossíntese, transpiração e condutância estomática ao longo do período de estresse. Assim, devido à sua resposta geral à seca, a planta 1329 do Ev.8 foi selecionada para multiplicação e futuros testes de competição em campo no nosso programa de melhoramento de porta-enxertos de citros, visando selecionar um genótipo de citrumelo Swingle mais tolerante ao déficit hídrico.

Termos de indexação: porta-enxertos, tolerância à seca, citros, OGM, veranico.

\section{INTRODUCTION}

In citrus production, water deficit is one of the most limiting abiotic factors to obtain high productivity. Dry spells cause molecular, physiological and morphological changes, which may generate significant economical losses in unadapted trees, especially when water deficits occur in the flowering, fruit set and fruit development periods (Albrigo \& Saúco, 2004; Gomes et al., 2014). In many areas worldwide, growers rely on irrigation to cope with water deficit periods. This management, however, requires an infrastructure that is not costly effective for most of the Brazilian citrus areas, which are primarily not irrigated. Because of that, there have been major efforts to improve the performance of plants frequently exposed to water deficits, specially with respect to rootstock (Pompeu Junior, 2005) and orchard (Ragozo et al., 2006) managments.

The predominant rootstock used in Brazilian orchards is Rangpur lime (Citrus limonia Osbeck), mainly due to its higher tolerance to water deficit (Pompeu Junior, 2005; Carlos et al., 1997). However, such a predominance has generated great vulnerability in Brazilian citrus orchards, especially to outbreaks of diseases. Citrus blight (Carlos et al., 2000) and sudden death (Bassanezi et al., 2003) are major examples of diseases that have caused extensive huge economic losses to the citrus production chain mainly in the border areas of São Paulo and Minas Gerais States, in Brazil. In addition, Rangpur lime is not considered superior to other rootstocks in terms of inducing high quality fruits. Alternatively, Swingle citrumelo (Citrus paradisi Macfad. cv. Duncan x Poncirus trifoliata L. Raf.) has been used as the main substitute to Rangpur lime because of favorable aspects in the canopy, including fair yield with higher fruit quality and tolerance to sudden death, gummosis, tristeza virus and blight (Embrapa, 2005; Pompeu Junior $\&$ Blumer, 2008). However, Swingle citrumelo is more susceptible to water deficit, which often restricts its use in many non-irrigated areas in Brazil (Pompeu Junior \& Blumer, 2008).

Swingle citrumelo is a hybrid resulted from the cross between Duncan grape fruit and Trifoliata. This hybridization was performed by Walter T. Swingle, in 1907, in Florida, USA (Hutchison, 1974), and its seeds were brought to Brazil by the Instituto Agronômico - IAC in the 1940s (Pompeu Junior, 2005). In 1999, it was present in only $5.3 \%$ of new citrus plants produced in nurseries in the State of São Paulo, but in the period between 2004 and 2007, growers' demand raised its usage to 20.4\% (Pompeu Junior et al., 2004; Pompeu Junior \& Blumer, 2008).

Water stress causes metabolic changes in plants (Oliveira et al., 2014) and affects several biochemical processes, such as osmotic adjustment, defense with antioxidant enzymes, lipid peroxidation, production of abscisic acid and reactive oxygen species (ROS), and other non-enzimatic compounds (Molinari, 2006; Khan et al., 2015). Plants have different survival responses to water deficit, which vary depending on the genotype, the duration and severity of stress, the developmental stage and the part of the plant that is mostly affected (Coscolin, 2012).

In order to survive in adverse environments, plants have developed various mechanisms that allow them to adapt to those conditions. Under water deficit, cells tend to raise the content of osmoprotectors such as the amino acid proline, sugar alcohols (e.g., sorbitol and mannitol) and glycine betaine - a quaternary amine (Taiz \& Zeiger, 2004). The osmotic adjustment helps the maintenance of cell turgor, the stabilization of proteins and cellular structures and contributes to the maintenance of important physiological processes, such as photosynthesis and the overall plant growth (Angelocci, 2002). The accumulation of proline is reported in plants under different stresses, such 
as drought, high salinity, low temperatures, UV radiation, etc. (Hayat et al., 2012).

In plants, the synthesis of proline may occur in two ways: primarily from glutamate, or from ornithine (Adams \& Frank, 1980). In the glutamate pathway, glutamate (L-Glu) is converted to glutamate semialdehyde (GSA), by a single bifunctional enzyme, the $\Delta 1$-pyrroline-5-carboxylate synthetase (P5CS). Glutamate semialdehyde is then cycled spontaneously to the pyrroline-5-carboxylate, and, subsequently, reduced to proline (L-Pro) by the enzyme Pyrroline-5-carboxylate reductase (P5CR). On this pathway, the enzyme P5CS is the limiting factor for the biosynthesis of proline in plants, due to the presence of mechanisms of inhibition by feedback (Hu et al., 1992; Zhang et al., 1995). By site directed mutagenesis, Zhang et al. (1995) substituted the phenylalanine amino acid by alanine at the position 129 in the P5CS enzyme isolated from Vigna aconitifolia, causing the inhibition of the feedback control while keeping the other properties of the enzyme intact. This achievement allowed Hong et al. (2000) to produce $P 5 C S-F 129 A$ transgenic plants able to accumulate proline, as well as Molinari et al., (2004) to produce transgenic Carrizo citrange (Citrus sinensis L. Osb. $\mathrm{x}$ Poncirus trifoliata L. Raf.) rootstock overproducing proline.

Campos et al. (2011) evaluated plants of Swingle citrumelo under water stress with the same P5CS-F129A transgene controlled by the constitutive CaMV35S promoter. They observed osmotic adjustment and reduced oxidative stress in transgenic plants, which contributed to the maintenance of gas exchange, keeping higher photosynthetic levels and lower lipid peroxidation compared to non-transgenic controls. However, constitutive production of proline may cause imbalance in the ratio of the proline content to the total amino acids and competition for carbon skeletons with the primary metabolism of N (Yamada et al., 2005; Araújo et al., 2014), eventually affecting important metabolic routes and impacting on plant growth and development. The use of stress-inducible promoters, such as those from the genes belonging to the Responsive to Desiccation family - RD (Yamaguchi-Shinozaki et al., 1992) from Arabidopsis thaliana, may represent an alternative strategy to avoid constitutive accumulation of gene products.

Therefore, the objective of this work was to evaluate under water deficit the performance of transgenic events of Swingle citrumelo containing the P5CS-F129A gene under the control of the stress induced $R D 29 A$ promoter. Selected plants will be used in future field trials by our rootstock breeding program, which aims to select new genotypes of Swingle citrumelo that are more tolerant to drought, but retaining the known performance and characteristics of non-transgenic plants.

\section{MATERIAL AND METHODS}

\section{Citrus Materials and Genetic Transformation}

Three genotypes of Swingle citrumelo (Citrus paradise Mac. cv. Duncan x Poncirus trifoliata L. Raf) were used: Non-transgenic control (NTC); Transgenic event 6 (Ev.6); and Transgenic event 8 (Ev.8). The genetic transformation experiments were conducted at the Biotechnology Laboratory (LBI) of the Agronomic Institute of Paraná (IAPAR), using the methodology described by Moore et al. (1992) and adapted by Campos \& Vieira (2006). Seeds were germinated in the dark and epicotyl segments were transversely cut and exposed to Agrobacterium tumefaciens, strain EHA105, harboring the $\mathrm{pIBI} 29$ vector containing the Vigna aconitifolia P5CS-F129A mutant gene (Zhang et al., $1995)$ under control of the $R D 29 A$ induced promoter (Yamaguchi-Shinozaki et al., 1992), the NOS terminator, the NPTII selection marker gene under the control of the CaMV35S promoter, conferring constitutive resistance to the antibiotic kanamycin, and the CaMV35Spoly terminator, as seem in Figure 1.

Cultivation of the Agrobacterium strain with the above construct was done at $28^{\circ} \mathrm{C}$ in YMB liquid medium supplemented with $20 \mathrm{mg} \mathrm{L}^{-1}$ of rifampicin and $30 \mathrm{mg} \mathrm{L}^{-1}$ of kanamycin. The culture was stirred $(140 \mathrm{rpm})$ for $24 \mathrm{~h}$ and after adjusting the bacterial concentration $\left(\mathrm{OD}_{600}=0.4\right)$, $1000 \mu \mathrm{L}$ of acetosyringone was added to $50 \mathrm{~mL}$ of the culture medium for further co-cultivation with the explants. For insertion confirmation, DNA was extracted according

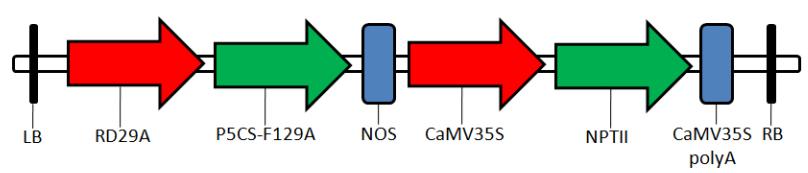

Figure 1. Agrobacterium T-DNA construction used for genetic transformation of Swingle citrumelo, containing the RD29A promoter for the Vigna aconitifolia P5CS-F 129 A mutant gene, nopaline synthase (NOS) terminator, CaMV35S promoter for the NPTII selection gene, terminator CaMV35SpolyA and the respective left $(\mathrm{LB})$ and right borders $(\mathrm{RB})$. 
to the protocol described by Doyle \& Doyle (1987) and optimized by Ferreira \& Grattapaglia (1996), and the analysis of the putative transformed plants was done by polymerase chain reaction (PCR) method, aiming at the detection of: 1) P5CS-F 129 A mutant gene, using the following oligonucleotide primers 5'AGC AAC TCA ACT CTC TCG GA3' and 5'CCA CTC TAG ACT TGT CGC CA3', and yielding the amplicon product of 589 bp; 2) RD29A promoter, 5'TCG GGA TTC GGT GAA TTG AGG AGA GAG G3' and 3'GAC GGT ACC TGA GTA AAA CAG AGG AGG TC5', and 700 bp; 3) NPTII selection gene, 5'ATC GGG AGC GGC GAT ACC GTA3' and 5'GAG GCT ATT CGC TAT GAC TGG3', and $700 \mathrm{bp}$; and 4) CaMV35S promoter of the NPTII gene, 5'GCT CCT ACA AAT GCC ATC A3' and5'ATA GTG GGA TTG TGC GTC A3', and 274bp. Each reaction $(25 \mu \mathrm{l})$ contained $2.5 \mu \mathrm{l} 10 \mathrm{x}$ PCR buffer, $1.6 \mu 110$ mM dNTP mix, $1.2 \mu 150$ mM MgCl, $0.5 \mu l$ of forward primer, $0.5 \mu \mathrm{l}$ of anti-sense primer, $0.2 \mu \mathrm{l}$ of Taq and $2 \mu \mathrm{l}$ of $50 \mathrm{mg} / \mathrm{ml}$ DNA. For the amplification of the P5CS-F129A, NPTII and CaMV35S fragments, the samples were submitted to the following temperature program: $1 \mathrm{~min}$ at $55^{\circ} \mathrm{C}$, followed by 35 amplification cycles $\left(3 \mathrm{~min}\right.$ at $94^{\circ} \mathrm{C}, 30 \mathrm{sec}$ at $55^{\circ} \mathrm{C}, 1 \mathrm{~min}$ at $72^{\circ} \mathrm{C}$ ) and final extension of $10 \mathrm{~min}$ at $72^{\circ} \mathrm{C}$, while for the $R D 29 \mathrm{~A}, 3 \mathrm{~min}$ at $94^{\circ} \mathrm{C}$, followed by 29 amplification cycles $\left(1 \mathrm{~min}\right.$ at $94^{\circ} \mathrm{C}, 30 \mathrm{sec}$ at $52^{\circ} \mathrm{C}, 1 \mathrm{~min}$ at $72^{\circ} \mathrm{C}$ ) and final extension of $5 \mathrm{~min}$ at $72^{\circ} \mathrm{C}$, both sets run at a PTC-100 Tм thermocycler (MJ Research, Walthan, MA, USA).

For the water deficit experiment, the candidate events were multiplied by vegetative propagation through cuttings, yielding root and canopy sprouts from the same plant stem. Five biological replicates with one plant each were used, totaling 15 experimental plants with the following individual identification numbers (IDs): NTC (1381, 1382, 1395, 1396 and 1397), Ev.6 (1336, 1337, 13511353 and 1354) and Ev.8 (1320, 1329, 1330, 1349 and 1350). The non-transgenic control (NTC) is a standard Swingle genotype, while the transgenic plants (Ev.6 and Ev.8) were obtained by Agrobacterium-mediated transformation.

The plants were kept in 7-liter vases, filled with organic substrate. Prior to the period of water stress, the plants received irrigation daily, as well as fertilization and phytosanitary treatments. A week before suspending irrigation, plants were pruned in order to standardize the volume of the canopy.

\section{Water deficit}

The plants were subjected to water deficit by suspending irrigation. They were irrigated again only when they reached the severe stress level, defined by the following values of water potential $(\Psi \mathrm{t})$ in $\mathrm{MPa}$ : no stress (NS: >-1.5 MPa); moderate stress (MS: -2.0 to $-2.9 \mathrm{MPa}$ ); severe stress (SS: -3.5 to $-4.8 \mathrm{MPa}$ ) and recovery (Rec $>-1.1 \mathrm{MPa}) 36 \mathrm{~h}$ after rehydration. The day before the beginning of the evaluations, the initial volume of water was standardized by irrigating the vases until they reached the point of substrate maximum water storage capacity. During the time when irrigation was suspended, the weight of the vases was periodically measured with the use of scales.

\section{Greenhouse conditions}

During the period of water deficit, a sensor for temperature and air humidity of the air (model HMP45C, Campbell Scientific, Logan, USA) was positioned between the evaluated plants. The sensor was connected to a system of automatic acquisition of data (model CR1000, Campbell Scientific, Logan, USA), which recorded the information of temperature and humidity every 15 minutes. From those measurements, the average, maximum and minimum temperatures and humidity were obtained on a daily basis. The temperature values ranged between 20.2 and $25.6{ }^{\circ} \mathrm{C}$ and the average relative humidity between 81.3 and $94.7 \%$.

\section{Leaf samples}

The monitoring of leaf water potential was performed by using thermocouple psychrometers (model C-30, Wescor, Inc., Logan, Ut, U.S.A.), connected to a data logger (Campbell Scientific, Inc., Logan, Ut, U.S.A., model CR-7). Two leaf discs of approximately $2 \mathrm{~cm}^{2}$ were collected from each plant, prepared in the chamber of psychrometers and sealed. Subsequently, they were connected to the data logger for readings, and the micro voltage measured by the device was converted into water potential (MPa). Sensors were calibrated with sodium chloride solutions. After connecting the psychrometers to the data logger, the reading was performed periodically, and once psychrometers were stabilized data was collected yielding the total potential $(\Psi \mathrm{t})$. 
In each sampling, approximately three leaves in same stage of development of each plant were collected at dawn, so that the leaf potential and the water potential were in balance, with absence of transpiration (stomata closed and in presence of reduced evaporative potential of the atmosphere). From this material four leaf discs were taken for the determination of water potential and water content, and the remaining leaf material immediately immersed in liquid- $\mathrm{N}_{2}$ and kept in freezer at $-80^{\circ} \mathrm{C}$ until use for analysis of proline contents.

\section{Relative Water Content (RWC)}

RWC was based on the technique described by Slavik (1974). Two discs of $2 \mathrm{~cm}^{2}$ were removed with a cutter from the collected leaves and weighted individually, thus obtaining the fresh weight (FW). Subsequently, the discs were soaked individually in distilled water, until they reach the point of maximum turgor, and then, again had their weight measured, obtaining the turgid weight (TW). After that, the discs were placed to dry in an oven at $60^{\circ} \mathrm{C}$ until stabilization of their weights and weighted again to obtain the dry weight (DW). From these measures, RWC was calculated using the ratio between the difference of fresh and dry weight over the difference of turgid and dry weight, as follows: RWC $=((\mathrm{FW}-\mathrm{DW}) /(\mathrm{TW}-\mathrm{DW})) * 100$.

\section{Net photosynthesis, stomatal conductance and transpiration}

Gas exchange measurements were obtained using the portable LCpro-SD photosynthesis model System (Serial No. 33074), with artificial light, under the density of photosynthetic photon flux of $800 \mu \mathrm{mol} \mathrm{m} \mathrm{m}^{-2} \mathrm{~s}^{-1}$. The measurements were carried out between 10:00 and 11:00 am, with leaves on the same developmental stage from the high middle third of the plants. Photosynthesis was expressed as $\mu \mathrm{mol} \mathrm{CO} \mathrm{m}^{-2} \mathrm{~s}^{-1}$, transpiration in $\mathrm{mmol} \mathrm{m} \mathrm{m}^{-2} \mathrm{~s}^{-1}$, and stomatal conductance in $\mathrm{mol} \mathrm{H}_{2} \mathrm{O} \mathrm{m}^{-2} \mathrm{~s}^{-1}$.

The results, represented by days and periods without irrigation were represented by the sum of the replicates of each treatment. This method was used since the suspension of irrigation was maintained until each plant had reached the severe stress condition, which occurred in different dates for the same treatment. Subsequently, the data was grouped in more representative periods without irrigation by calculating the mean of the evaluated parameter.

\section{Quantification of the proline content}

The determination of the proline content was based on the methodology described by Bates et al. (1973), with some modifications. Approximately $50 \mathrm{mg}$ of leaf tissue, previously ground in liquid $\mathrm{N}_{2}$, was homogenized in $10 \mathrm{~mL}$ of sulfosalicylic acid 3\% (w/v). After centrifugation (7500 rpm) for $10 \mathrm{~min}, 1 \mathrm{~mL}$ of extract of each sample, (without stress, with moderate stress and in recovery) and $0.5 \mathrm{~mL}$ of the sample submitted to severe stress, were collected and completed until the volume of $2 \mathrm{~mL}$, by additing sulfosalicylic acid $3 \%(\mathrm{w} / \mathrm{v})$ in microcentrifuge tubes of $15 \mathrm{~mL}$. To this solution $2 \mathrm{~mL}$ ninhydrin acid solution (1.25 g of ninhydrin; $30 \mathrm{~mL}$ glacial acetic acid; $20 \mathrm{~mL}$ of phosphoric acid $6 \mathrm{M}$ ) and $2 \mathrm{~mL}$ of glacial acetic acid was added. The samples were then incubated at $100^{\circ} \mathrm{C}$ for one hour and then placed on ice. To this solution $4 \mathrm{~mL}$ of toluene was added, followed by shaking for 20 seconds to complete the extraction of proline. The supernatant was used for reading in a spectrophotometer at $520 \mathrm{~nm}$ and the absorbance compared to the standard curve of proline. The standard curve was performed using the concentrations of $0,20,40,6080$ and $100 \mu \mathrm{gmL}^{-1}$ of proline, and the readings were adjusted by linear equation, which obtained $\mathrm{R}^{2}$ of 0.99 . The analyses were done in triplicate and the results obtained were expressed in micromols of proline per gram of fresh weight $\left(\mu \mathrm{mol} \mathrm{g}{ }^{-1} \mathrm{FW}\right)$.

\section{Experimental design}

The experimental design was completely randomized, with the assessment of the three genotypes, namely non-transgenic control (NTC); transgenic event 6(Ev.6); and transgenic event 8 (Ev.8), each consisting of five biological replicates, represented by individual plants. Those were subjected to days without irrigation (d.w.i.), studying the regression between the variables over the time. The results were also grouped by periods of d.w.i. and subsequently submitted to analysis of variance and comparison of means by Scott-Knott test, at 5\% of probability, using the Assistat software. Graphs and adjustments of polynomial curves were obtained using the Excel program.

The data of net photosynthesis, transpiration, stomatal conductance and correlation between potential and water content of the three genotypes were used to find the mathematical models that best fit their progress over the time (d.w.i.), and the choice for the quadratic model was made based on values of $\mathrm{R}^{2}$ and significance of $\mathrm{F}$ (ANOVA). 


\section{RESULTS AND DISCUSSION}

\section{Free proline content}

The analysis of free proline in the leaves of non transgenic control (NTC) plants and in events 6 (Ev.6) and 8 (Ev.8), harboring the RD29A:VaP5CS-F129A construct, revealed that during the period of suspension of irrigation the Ev. 8 transgenic plants had a significantly higher proline content than the other treatments (Figure 2). Although a small increase in free proline was observed in Ev.6, this was not significantly superior to the NTC (Figure 2).

Under no stress condition (NS), the accumulation of free proline in the leaves of Ev. 8 was already $88 \%$ higher than in the control, and Ev. 6 was superior by $22 \%$. Although $R D 29 A$ is a stress-induced promoter, most likely its basal activation occurred in the transgenic events even without drought stress.

Under moderate stress (MS), all three genotypes showed an increase in the content of free proline, which is expected when plants are subjected to water deficit (Figure 2). However, in Ev.8, the level of free proline was $66 \%$ higher and significantly different from the control.

Upon reaching severe stress (SS), the levels of free proline reached the maximum levels measured during the evaluation period. While the transgenic events had

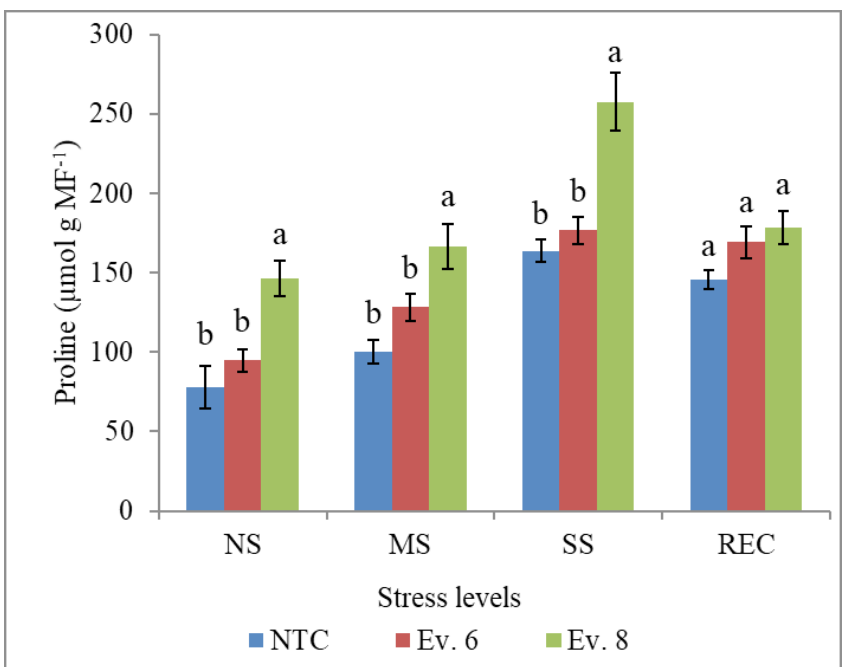

Figure 2. Free proline concentration in control plants and in non-transgenic control (NTC) plants and events 6 (Ev.6) and 8 (Ev.8), both transformed with the gene VaP 5CS-F129A, under control of the stress-induced $R D 29 A$ promoter. The values represent the means \pm standard errors. The comparison of means in each stress level was performed by Scott-Knott test, at 5\% of probability. the lowest increments of free proline at this point, since Ev. 6 and Ev. 8 have surpassed the NTC in only $8 \%$ and $57 \%$ respectively, in absolute quantities Ev. 8 reached the largest difference compared to the control, surpassing it in $93.69 \mu \mathrm{mol}$ of free proline $\mathrm{g}^{-1}$ of fresh tissue.

During the recovery (REC), the transgenic events still showed levels of free proline slightly higher but not significantly different from the control. At this stage, the level of free proline in Ev. 8 was closest to the NTC, with rehydration of plants, probably because of repression of genes responsible for the production of the osmolyte, such as P5CS and increased expression of proline dehydrogenase (ProDH), which catalyzes the first stage of proline degradation, similarly to the results found by Sharma \& Verslues (2010).

\section{Net photosynthesis}

As expected, the net photosynthesis was decreased upon drought stress and was only raised again when plants were rehydrated after the severe stress level. Until the $10^{\text {th }}$ day without irrigation (d.w.i.), the net photosynthesis suffered no major changes; however, from this period and beyond, there was a strong decline, which occurred most significantly in the NTC plants, followed by the Ev.6 (Figure 3A). In the $16^{\text {th }}$ d.w.i., Ev. 8 surpassed the photosynthetic level of the NTC, as well as Ev.6, remaining higher until the end of the experiment. The water deficit applied in the experiment allowed the evaluation the NTC and Ev.6 plants only until the $22^{\text {nd }}$ and $26^{\text {th }}$ d.w.i., respectively. On the other hand, Ev. 8 was evaluated until the $31^{\text {st }}$ day, indicating greater tolerance of those conditions of water deficit (Figure 3A).

When grouping net photosynthesis in periods of d.w.i. for better representing the drought periods, it was possible to observe that the NTC and the Ev. 6 maintained the photosynthetic levels significantly higher than Ev. 8 from 0 up to 10 d.w.i (Figure 3B). However, there were no visible differences in the development of the plants. Between the $14^{\text {th }}$ and $17^{\text {th }}$ d.w.i. the plants presented a sharp fall in net photosynthesis due to water restriction, with no significant differences among the three genotypes.

With even more reduced water availability, Ev. 8 showed better photosynthetic performance than the NTC and the Ev. 6 between $18^{\text {th }}$ and $22^{\text {nd }}$ d.w.i., while all plants of the non-transgenic genotype had already reached severe water stress level at the $22^{\text {nd }}$ d.w.i (Figure 3B). 
In the period between the $24^{\text {th }}$ and $26^{\text {th }}$ d.w.i., data was collected only from Ev.8 and Ev.6, since the NTC was no longer under analysis. In this period, both genotypes showed low photosynthetic levels and did not differ from one another. At the end of this period, the last data collection of Ev. 6 was performed, because they also reached severe stress level. Between the $28^{\text {th }}$ and $31^{\text {st }}$ d.w.i. only the Ev. 8 was analyzed (Figure 3B).

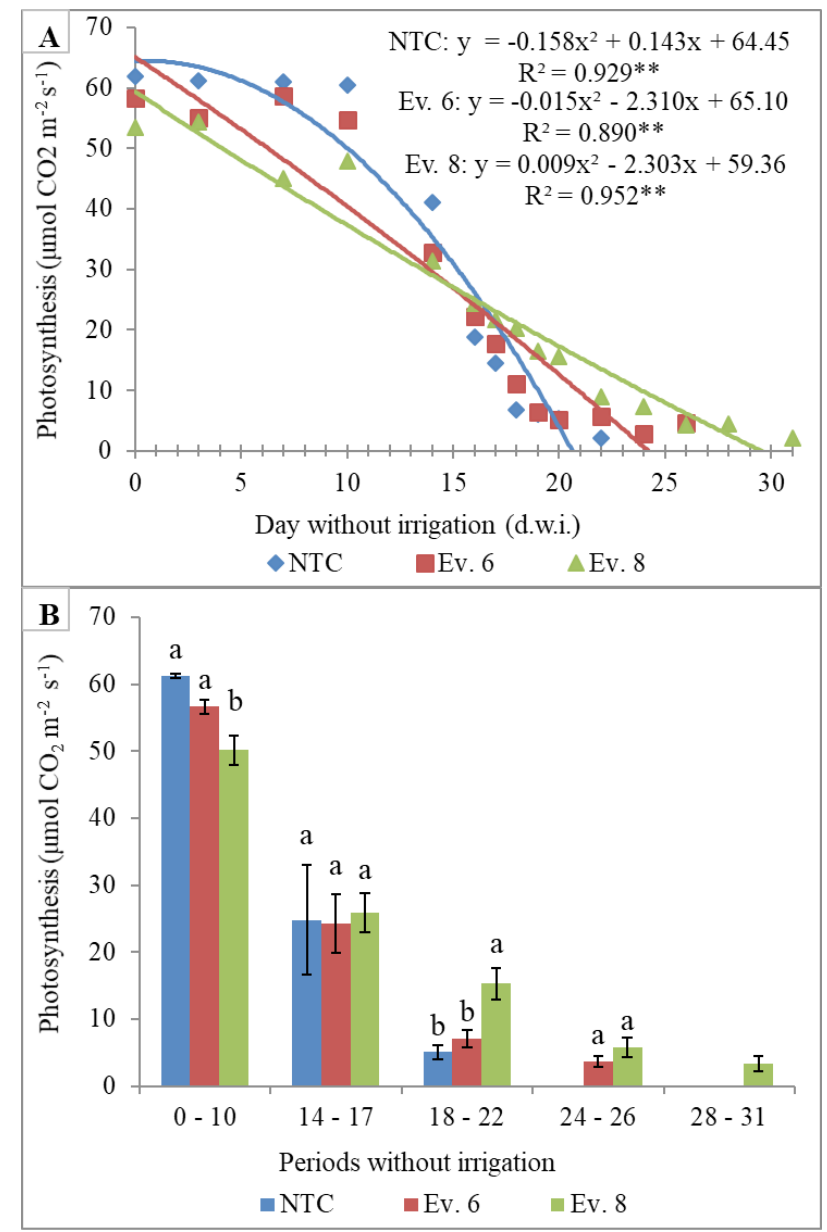

Figure 3. Net photosynthesis over day without irrigation (d.w.i.) of non-transgenic control (NTC) plants and events 6 (Ev.6) and 8 (Ev.8), both transformed with the gene VaP5CS-F129A, under control of the stress-induced $R D 29 A$ promoter. (A) Regression showing the evolution of net photosynthesis with the advancement of water deficit (d.w.i.); values represent the sum of each data point; (B) Grouping of net photosynthesis in periods; values represent the mean of the period. Vertical bars represent \pm standard errors, and comparison of means in each period was performed by Scott-Knott test, at 5\% of probability. ${ }^{*}$ Significant regression coefficient at $1 \%$ of probability.

\section{Transpiration}

As photosynthesis, the transpiration declined in the period evaluated, as observed in Figure 4A and B. Until the $16^{\text {th }}$ day, event 8 presented values of transpiration inferior to the other treatments; however, from this date on, both control and event 6 had lower rates of transpiration, declining rapidly until they reached severe stress. When grouped into the

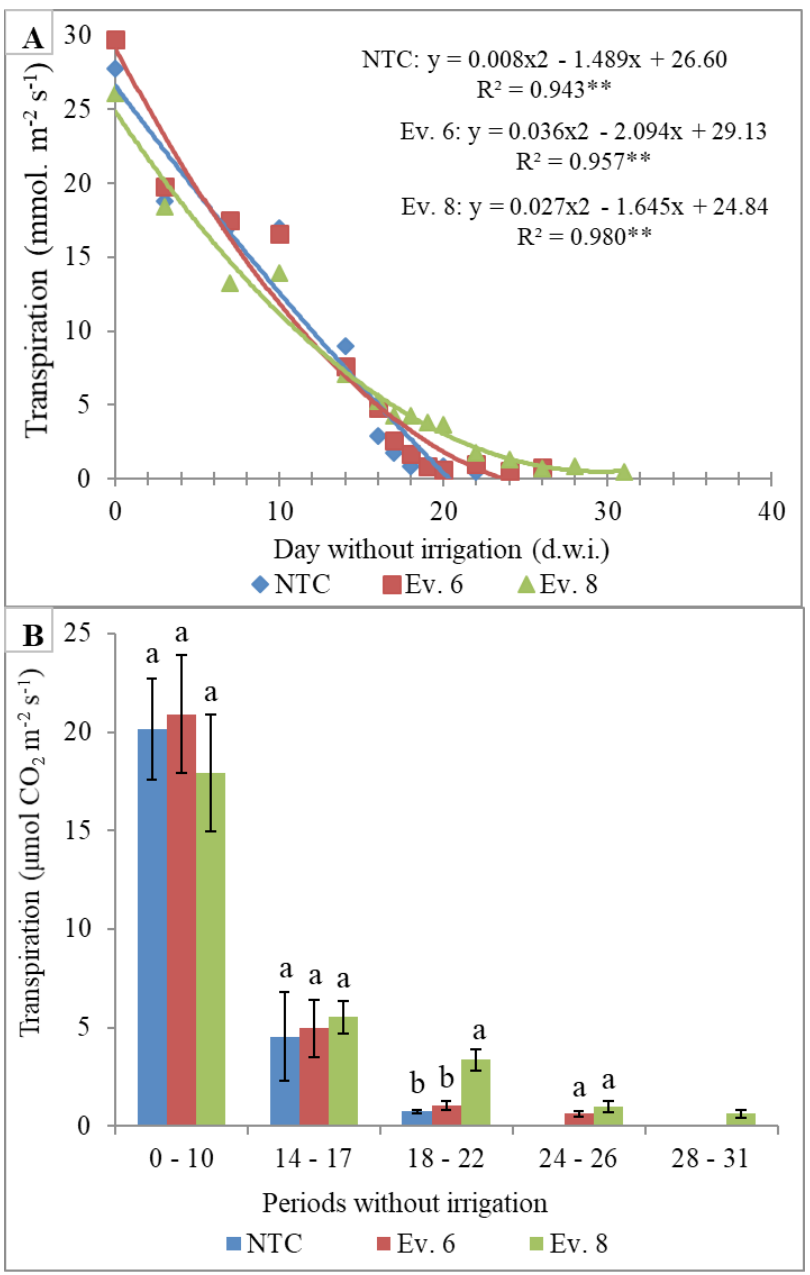

Figure 4. Transpiration over day without irrigation (d.w.i.) of non-transgenic control (NTC) plants and events 6 (Ev.6) and 8 (Ev.8), both transformed with the gene VaP5CS-F129A, under control of the stress-induced $R D 29 A$ promoter. (A) Regression showing the evolution of transpiration with the advancement of water deficit (d.w.i.); values represent the sum of each data point; (B) Grouping of transpiration in periods; values represent the mean of the period. Vertical bars represent \pm standard errors, and comparison of means in each period was performed by Scott-Knott test, at $5 \%$ of probability. **Significant regression coefficient at $1 \%$ of probability. 
same periods used for the analysis of photosynthesis, event 8 showed reduced value of transpiration, followed by the control and event 6 (Figure 4B). However, this difference was not significant up to the $17^{\text {th }}$ d.w.i. On the other hand, in the period between $18^{\text {th }}$ and $22^{\text {nd }}$ d.w.i., event 8 kept values significantly higher than the control and event 6 . With the increase in water deficit, between the $24^{\text {th }}$ and $26^{\text {th }}$ d.w.i., event 8 showed transpiration values slightly superior than event 6 but not significantly different, while the non-transgenic plants had already been withdrawn from the experiment. Due to its superior stress tolerance, event 8 was still under evaluation from day 28 to 31 , when the experiment was terminated.

\section{Stomatal conductance}

The stomatal conductance decreasead throughout the evaluation period (Figure 5A and B). Stomatal closure is one of the first consequences of water stress in plants, causing decrease in diffusion of $\mathrm{CO}_{2}$ in the leaf mesophyll, and consequently, dropping the photosynthesis level (Souza et al., 2001). A more pronounced decline was mainly observed in the analysis performed between the $14^{\text {th }}$ and $17^{\text {th }}$ d.w.i. (Figure 5A), when the water supply available to plants became the limiting factor. The NTC and Ev.6 had a more noticeable decline than Ev. 8 from the $18^{\text {th }}$ d.w.i. and beyond (Figure 5B). Within $24^{\text {th }}$ and $26^{\text {th }}$ d.w.i., Ev.6 and Ev.8 showed reduced stomatal conductance, and only this last event was able to remain in conditions to be further evaluated at the $31^{\text {st }}$ d.w.i.

\section{Relation between water potential and relative water content (RWC)}

The total water potential and RWC measured in all genotypes were adjusted by a regression analysis (Figure 6), generating a quadratic equation $\left(y=-2.254 \mathrm{x}^{2}-0.282 \mathrm{x}+94.29\right)$ that demonstrated the high relationship between these two variables $\left(\mathrm{R}^{2}=0.911\right)$.

\section{Visual evaluation of plants under stress}

It was possible to monitor the advance of the stress in all three genotypes. Figure 7 shows the plants from the beginning of the experiment, under no water stress condition, up to 22 days without irrigation. NTC and Ev.6 were mostly affected, followed by Ev.8 showing mild symptoms of stress.

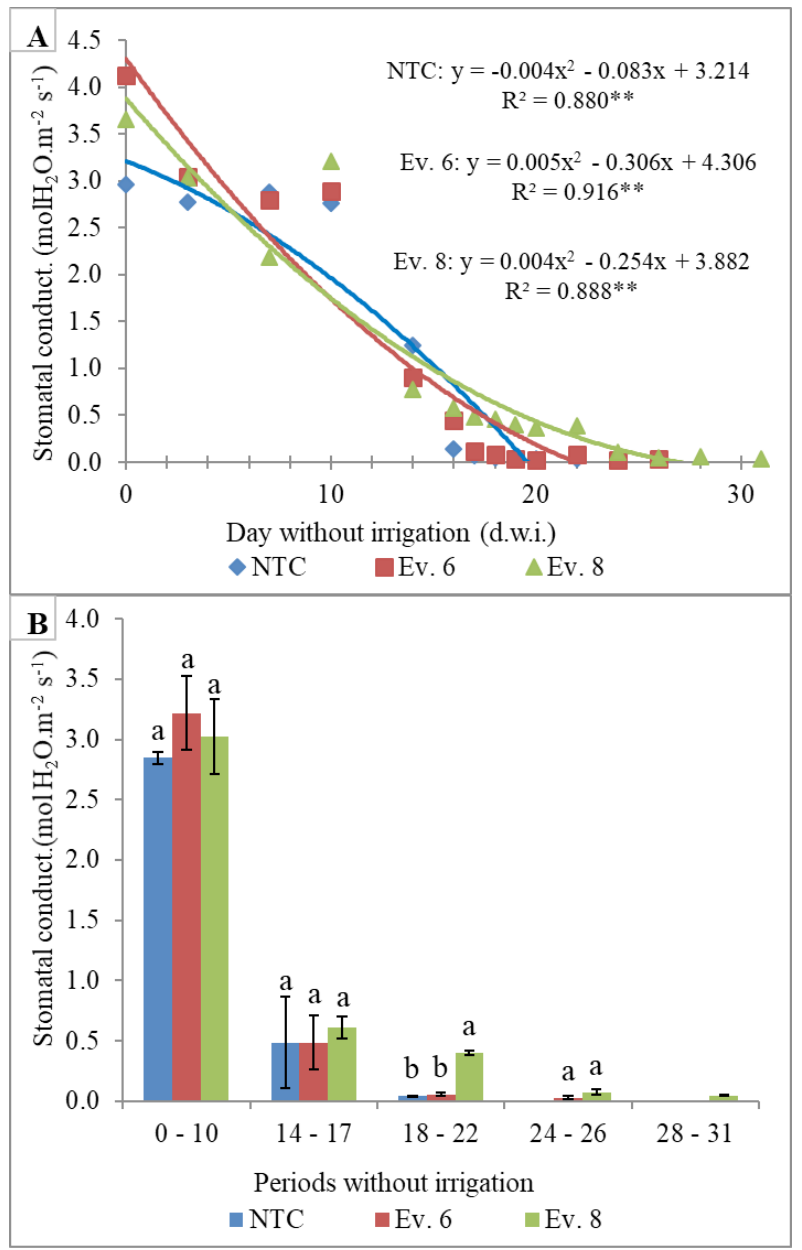

Figure 5. Stomatal Conductance over day without irrigation (d.w.i.) of non-transgenic control (NTC) plants and events 6 (Ev.6) and 8 (Ev.8), both transformed with the gene VaP5CS-F129A, under control of the stress-induced RD29A promoter. (A) Regression showing the evolution of stomatal conductance with the advancement of water deficit (d.w.i.); values represent the sum of each data point; (B) Grouping of stomatal conductance in periods; values represent the mean of the period. Vertical bars represent \pm standard errors, and comparison of means in each period was performed by Scott-Knott test, at $5 \%$ of probability. **Significant regression coefficient at $1 \%$ of probability.

The plant 1329 of the Ev. 8 was the last one evaluated, better tolerating the water stress condition up to 31 d.w.i.

\section{Confirmation of transgenic plants}

The transformation experiment of Swingle citrumelo rootstock yielded 232 candidate explants that survived to Kanamycin selective pressure, but 


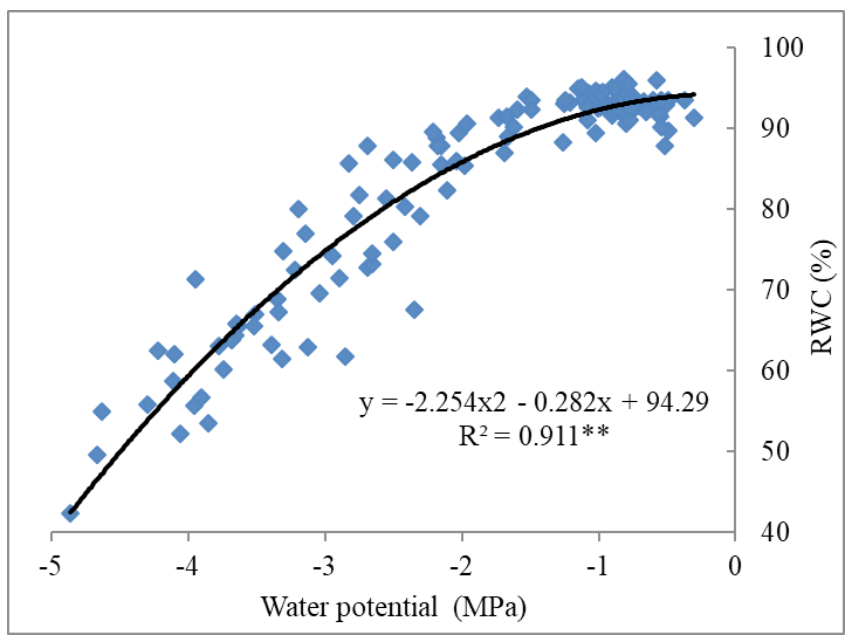

Figure 6. Relation between water potential and relative water content (RWC) represented by quadratic equation, using data of non transgenci control (NTC) plants and events 6 (Ev.6) and 8 (Ev.8), both transformed with the gene VaP5CS-F129A, under control of the stress-induced RD29A promoter. Condition without stress (WS) had Relative Water Content (RWC) above 89.6\%; moderate stress (MS) had RWC between $76.2 \%$ and $85.8 \%$; severe stress (SS) had RWC between $43.7 \%$ and $67.7 \%$; and recovery (REC) had RWC restored to above 91.9\%. $* *$ Significant regression coefficient at $1 \%$ of probability.

PCR analyzes indicated the presence of the RD29A promoter and the P5CSF $129 \mathrm{~A}$ transgene in only nine plants (Figure 8), giving a transformation efficiency of $3.88 \%$.

The selected plants 1336 (Ev.6) and 1329 (Ev.8) were evaluated for a longer period, respectively of 24 and 31 days without irrigation (d.w.i.). All other plants reached severe stress damage and were removed from the experiment. Both plants were again submitted to PCR analysis and the plant 1329 (Ev.8) was confirmed to be transgenic (Figure 9). The plant 1336 (Ev.6) displayed only the fragment product of $272 \mathrm{bp}$ from the CaMV35S promoter driving the NPTII marker gene, and could not be considered harboring the intact cassette of genes used during the transformation effort. On the other hand, the plant 1329 (Ev.8) displayed the expected products of 589bp, $700 \mathrm{bp}$ and $274 \mathrm{bp}$, corresponding to fragments from the P5CS-F129A, the NPTII and the CaMV35S promoter driving the marker gene respectively. This transgenic plant (1329) was saved for future use in plant breeding program, because it also had superior performance in all other evaluated physiological parameters.
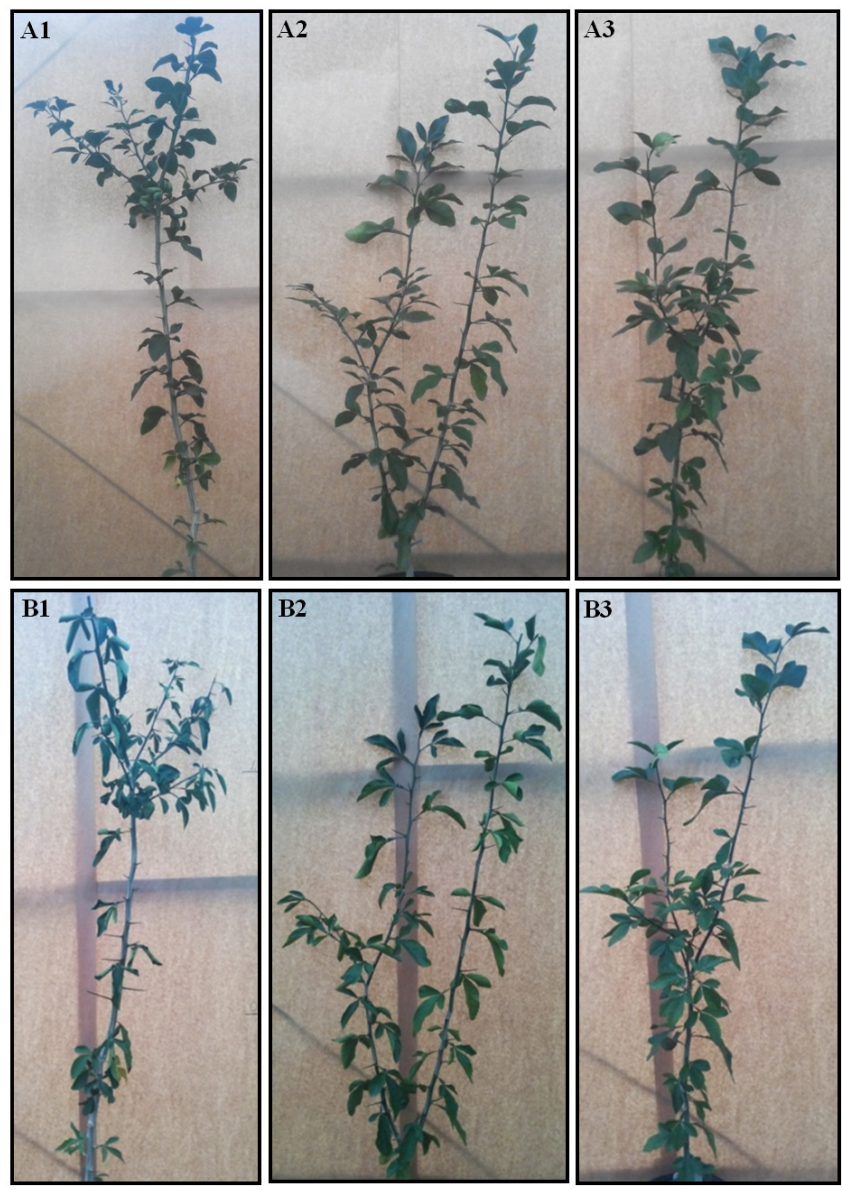

Figure 7. Picture of all genotypes evaluated in the experiment: non-transgenic control (NTC) plants and events 6 (Ev.6) and 8 (Ev.8). (A1) NTC, (A2) Ev.6 and (A3) Ev.8 under no stress; (B1) NTC, (B2) Ev.6 and (B3) Ev.8 after 22 days without irrigation (d.w.i.).

\section{Breeding program perspectives}

The increment of proline in transgenic plants compared to the non-transgenic control plants was expected with the progression of the water deficit (Figure 2), since the regulation of the VaP5CS-F129A gene was under control of the stress-induced promoter (RD29A). Campos et al. (2011), using the same gene for transforming plants of Swingle citrumelo, but under control of the constitutive promoter CaMV35S, observed around 2.5 times more proline in transgenic plants than in the control, even without stress. However, no significant increments of free proline in those transgenic plants were observed after water deficit compared to the irrigated conditions, while the control plants only accumulated free proline at similar levels to those obtained in transgenic plants at the 
severe water stress level. From this work, it is possible that the clonal descendents of the plant 1329 may stand a period of drought in better agronomical conditions than the constitutive CaMV35S:VaP5CS-F129A transgenic Swingle, because it will raise the free proline content

A)

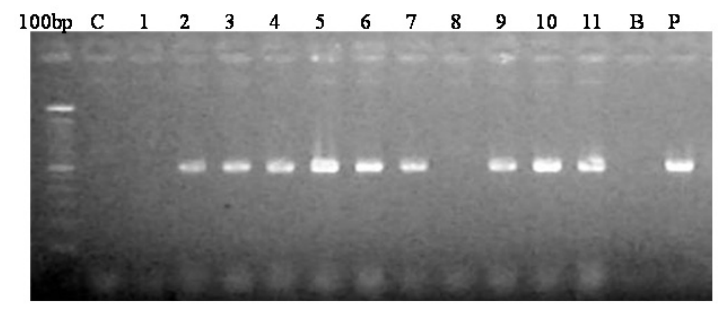

B)

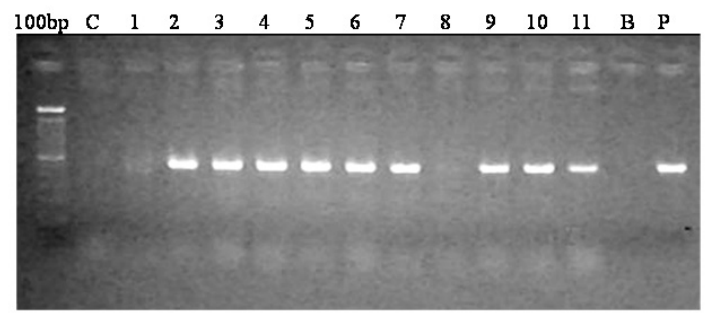

Figure 8. Exemple of PCR analysis of candidate Swingle citrumelo transformation events. Amplification of: (A) RD29A fragment; and (B) P5CS-F129A fragment. Lanes showing: $100 \mathrm{pb}$ - Molecular weight marker; C - Non-transgenic control plant; Transgenic plant lines 2-7 and 9-11; B - Negative control; P - Positive control (plasmid pBI-P5CS-F129A). to mitigate water stress only under stress conditions, which may limit the pleiotropic effects caused by the overexpression of the transgene.

Some studies reported that the exogenous application of proline may cause toxic effects, such as damage in ultrastructure of mitochondria and chloroplasts (Hare et al., 2002; Nanjo et al., 2003). However, no damage or negative visual effect was observed in the transgenic plant 1329, similarly to also found by Borgo et al. (2015).

With the advancement of the water deficit, photosynthesis decreased in all evaluated genotypes (Figure 03), but most markedly in the non-transgenic control plants. From the $18^{\text {th }}$ d.w.i. onward, Ev. 8 showed higher values of photosynthesis and remained with better physiological conditions for more time, which is in agreement with the results obtained by other authors (Campos et al., 2011; Molinari et al., 2007). In addition, Molinari et al. (2004), using transgenic Carrizo citrange with high levels of free proline, observed better photosynthetic rates in transgenic plants at severe water deficit conditions, when the highest levels of this amino acid were achieved.

The superior performance in photosynthesis may be decisive in situations of critical spring and summer periods, with unexpected dry spells during flowering and fruit set. It can be expected that plant 1329, by promoting higher fixation of carbon and suffering less oxidative damages during this water stress period, may result in better productivity.

It was clearly observed that there was a simultaneous fall of photosynthesis, transpiration and stomatal
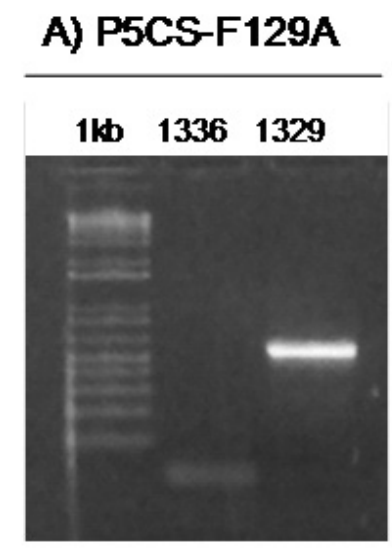

B) NTPI

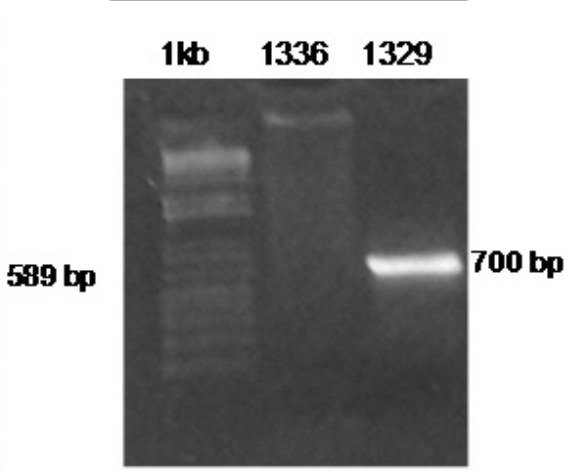

C) CaMN35S

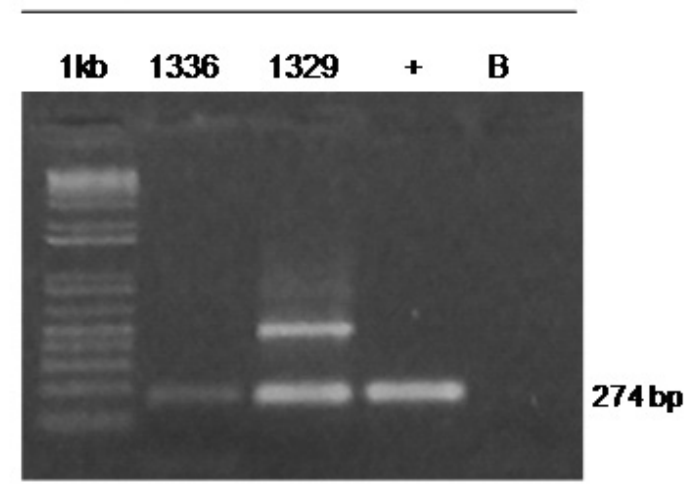

Figure 9. Polymerase chain reaction (PCR) of the remaining plants numbered 1336 (Ev.6) and 1329 (Ev.8). (A) Amplification fragment of 589 base-pairs (bp) from the P5CS-F129A gene; (B) 700 bp from the NPTII gene; and (C) $274 \mathrm{bp}$ from the CaMV35S promoter controlling the marker gene. Amplicons were run in 2\% agarose gel with $1 \mathrm{~kb}$ DNA marker and respective controls (+ for positive; and B for negative). 
conductance within the intermediate water stress period of $14^{\text {th }}$ to $17^{\text {th }}$ d.w.i. (Figures 3, 4 and 5). This probably occurs because even during a mild water restriction there is the imperative stimulus to stomatal closure, which acts as a mechanism to reduce water loss by transpiration and, as consequence, improves the efficiency in its use. On the other hand, the resultant reduction in the diffusion of $\mathrm{CO}_{2}$ affects the activity of the Rubisco enzyme (Chaves et al., 2009). In this study, Ev. 8 showed from the $18^{\text {th }}$ d.w.i. and beyond, superior photosynthetic levels compared to the other genotypes. Higher levels of free proline accumulated at the intermediated water deficit level by plant 1329 may have contributed to this performance.

The use of genetic transformation tools opens innumerous opportunities for citrus breeding. Rootstocks are the basis for any successful citrus industry worldwide and transgenic Swingle citrumelo plants transformed with the P5CS gene under control of stress-induced promotors (e.g., plant 1329) seems a promising alternative for future evaluations in the field as a new cultivar of citrus rootstock.

\section{ACKNOWLEDGEMENTS}

Authors are thankful to Getúlio Takashi Nagashima for kindly providing laboratory equipment, to Lucinéia Maria da Silva and Suely Ario Kudo for their total dedication to the success of this work, to CAPES (Coordenação de Aperfeiçoamento de Pessoal de Nível Superior) for granting the scholarship to Renato Farinacio, and to the graduation program at IAPAR.

\section{REFERENCES}

Adams E \& Frank L (1980) Metabolism of proline and the hydroxyprolines. Annual Review of Biochemistry 49: 1005-1061.

Albrigo LG \& Saúco VG (2004) Flower bud induction, flowering and fruit-set of some tropical and subtropical fruit tree crops with special reference to citrus. Acta Horticulturae (632): 81-90.

Angelocci LR (2002) Água na planta e trocas gasosas/ energéticas com a atmosfera: introdução ao tratamento biofísico. Piracicaba: FEALQ. 272 p.

Araújo WL, Martins AO, Fernie AR \& Tohge T (2014) Oxoglutarate: linking TCA cycle function with amino acid, glucosinolate, flavonoid, alkaloid, and gibberellin biosynthesis. Frontiers in Plant Science 5(552): 1-6.

Bassanezi RB, Bergamin Filho A, Amorim L, GimenesFernandes N, Gottwald TR \& Bové JM (2003) Spatial and temporal analyses of citrus sudden death as a tool to generate hypotheses concerning its etiology. Phytopathology 93(4): 502-512.

Bates LS, Waldren RP \& Teare ID (1973) Rapid determination of free proline for water stress studies. Plant and Soil 39(1): 205-207.

Borgo L, Marur CJ \& Vieira LGE (2015) Effects of high proline accumulation on chloroplast and mitochondrial ultrastructure and on osmotic adjustment in tobacco plants. Acta Scientiarum 37(2): 191-199.

Campos MKF \& Vieira LGE (2006) Transformação genética de porta-enxertos para citrus spp. visando a obtenção de plantas com maior tolerância ao déficit hídrico. Anais do XIV Seminário do Programa Institucional de Bolsas de Iniciação Científica, Londrina, p. 28.

Campos MKF, Carvalho K, Souza FS, Marur CJ, Pereira LFP, Bespalhok Filho JC \& Vieira LGE (2011) Drought tolerance and antioxidant enzymatic activity in transgenic 'Swingle'citrumelo plants over-accumulating proline. Environmental and Experimental Botany 72: 242-250.

Carlos EF, Lemos EGM \& Donadio LC (2000) O declinio dos citros. Laranja 21: 175-203.

Carlos EF, Stuchi ES \& Donadio LC (1997) Porta-enxertos para a citricultura paulista. Jaboticabal: FUNEP/UNESP. $47 \mathrm{p}$.

Chaves MM, Flexas J \& Pinheiro C (2009) Photosynthesis under drought and salt stress: regulation mechanisms from whole plant to cell. Annals of Botany 103: 551-560.

Coscolin RBS (2012) Efeitos fisiológicos e bioquímicos induzidos por deficienciahidrica em plantas de Ocimum basilicum L. Dissertação de Mestrado, Faculdade de Ciências Agronômicas, Universidade Estadual Paulista, Botucatu.

Doyle JJ \& Doyle JL (1987) Isolation of plant DNA from fresh tissue. Focus 12: 13-15.

EMBRAPA - Empresa Brasileira de Pesquisa Agropecuária (2005) Sistema de Produção para Pequenos Produtores de Citros do Nordeste. Brasília: Embrapa Mandioca e Fruticultura Tropical. Available on: < https:// sistemasdeproducao.cnptia.embrapa.br/FontesHTML/ 
Citros/CitrosNEPequenosProdutores/autores.htm>. Accessed on: 5 Nov. 2016.

Ferreira ME \& Grattapaglia D (1996) Introdução ao uso de marcadores moleculares em análise genética. Brasília: Embrapa Recursos Genético e Biotecnologia. 222 p.

Gomes FG, Lorenzi CO, Viana MM \& Boteon M (2014) Citrus. Hortifruti Brasil 12(132): 36-36.

Hare PD, Cress WA \& Vanstaden J (2002) Disruptive effects of exogenous proline on chloroplast and mitochondrial ultrastructure in Arabidopsis leaves. South African Journal of Botany 68(3): 393-396.

Hayat S, Hayat Q, Alyemeni MN, Wani AS, Pichtel J \& Ahmad A (2012) Role of proline under changing environments - A review. Plant Signaling \& Behavior 7(11): 1456-1466.

Hong Z, Lakkineni K, Zhang Z \& Verma DP (2000) Removal of feedback inhibition of delta-1-pyrroline5-carboxylate synthetase results in increased proline accumulation and protection of plants from osmotic stress. Plant Physiology 122(4): 1129-1136.

Hu CA, Delauney AJ \& Verma DPS (1992) A bifunctional D1-enzymepyrroline-5-carboxylate synthetase catalyzes the first two steps in proline biosynthesis in plants. Proceedings of the National Academy of Sciences of the United States of America 89: 9354-9358.

Hutchison DJ (1974) Swingle citrumelo - a promising rootstock hybrid. Florida State Horticultural Society 87: 89-91.

Khan MS, Ahmad D \& Khan MA (2015) Utilization of genes encoding osmoprotectants in transgenic plants for enhanced abiotic stress tolerance. Electronic Journal of Biotechnology 18(4): 257-266.

Molinari HBC (2006) Expressão estresse-induzida do gene P5CS em plantas transgênicas de cana-de-açúcar submetidas ao déficit hídrico. Tese de Doutorado, Universidade Federal do Paraná, Curitiba.

Molinari HBC, Marur CJ, Bespalhok Filho JC, Kobayashi AK, Peleggi M, Leite Jr RP, Pereira LFP \& Viera LGE (2004) Osmotic adjustment in transgenic citrus rootstock Carrizo citrange (Citrus sinensis Osb. x Poncirus trifoliata L. Raf.) overproducing proline. Plant Science 167: 1375-1381.

Molinari HBC, Marur CJ, Daros E, Campos MKF, Carvalho JFRP, Bespalhok Filho JC, Pereira LFP \& Vieira LGE (2007) Evaluation of the stress-inducible production of proline in transgenic sugarcane (Saccharum spp.): osmotic adjustment, chlorophy II fluorescence and oxidative stress. Physiologia Plantarum 130: 218-229.

Moore GA, Jacano CC \& Neidigh JL (1992) Agrobacteriummediated transformation of citrus stem segments and regeneration of transgenic plants. Plant Cell Reports 11: 238-242.

Nanjo T, Fujita M, Seki M, Kato T, Tabata S \& Shinozaki K (2003) Toxicity of free proline revealed in an Arabidopsis T-DNA-tagged mutant deficient in proline dehydrogenase plant. Cell Physiology 44(5): 541-548.

Oliveira CS, Carlos EF, Vieira LGE, Lião LM \& Alcantara GB (2014) HR-MAS NMR metabolomics of 'Swingle' citrumelo rootstock genetically modified to overproduce proline. Magnetic Resonance in Chemistry 52(8): 422-429.

Pompeu Junior J \& Blumer S (2008) Laranjeiras e seus porta-enxertos nos viveiros de mudas cítricas do Estado de São Paulo. Laranja 29(1-2): 35-50.

Pompeu Junior J (2005) Porta - Enxertos. In: Mattos Junior D, De Negri JD, Pio RM \& Pompeu Junior J (Eds). Citros. Campinas: Instituto Agronômico e Fundag, p. 61-104.

Pompeu Junior J, Salva R \& Blumer S (2004) Copas e porta-enxertos nos viveiros de mudas cítricas do Estado de São Paulo. Laranja 25(2): 413-426.

Ragozo CRA, Leonel S \& Crocci AJ (2006) Adubação verde em pomar cítrico. Revista Brasileira de Fruticultura 28(1): 69-72.

Sharma S \& Verslues PE (2010) Mechanisms independent of abscisic acid (ABA) or proline feedback have a predominant role in transcriptional regulation of proline metabolism during low water potential and stress recovery. Plant, Cell \& Environment 33: 1838-1851.

Slavik B (1974) Methods of studing plant water relations. Prague: Academy of Science. 449 p.

Souza CR, Soares AM \& Regina MA (2001) Trocas gasosas de mudas de videira, obtidas por dois porta-enxertos, submetidas à deficiência hídrico. Pesquisa Agropecuária Brasileira 36(10): 1222-1230.

Taiz L \& Zeiger E (2004) Fisiologia vegetal. 3. ed. Porto Alegre: Artmed. 719 p.

Yamada M, Morishita H, Urano K, Shiozaki N, YamaguchiShinozaki K, Shinozaki K \& Yoshiba Y (2005) Effects of 
free proline accumulation in petunias under drought stress. Journal of Experimental Botany 56(417): 1975-1981.

Yamaguchi-Shinozaki K, Koizumi M, Urao S \& Shinozaki K (1992) Molecular cloning and characterization of 9 cDNAs for genes that are responsive to desiccation in Arabidopsis thaliana: sequence analysis of one cDNA clone that encodes a putative transmembrane channel protein. Plant \& Cell Physiology 33: 217-224.
Zhang CS, Lu Q \& Verma DPS (1995) Removal of feedback inhibition of delta-1-pyrroline-5-carboxylate synthetase, a bifunctional enzyme catalyzing the first 2 steps of proline biosynthesis in plants. The Journal of Biological Chemistry 270(35): 20491-20496.

Received: February 10, 2017 Accepted: October 23, 2017 